\title{
Pectins from Apple Pomace
}

\author{
Márcia V. Marcon, Lúcia C. Vriesmann, Gilvan Wosiacki, Eliana Beleski-Carneiro \\ Universidade Estadual de Ponta Grossa, PR
}

\section{Carmen L. 0. Petkowicz, Departamento de Bioquímica e Biologia Molecular, UFPR}

\begin{abstract}
Extractions of apple pectins from apple pomace were performed using an experimental design with $2^{2}$ factorial. The extractor agent was $5 \%(\mathrm{w} / \mathrm{v})$ citric acid and the variables were time (30,50 and $80 \mathrm{~min})$ and temperature $(50,75$ and $\left.100^{\circ} \mathrm{C}\right)$. The best yield $(16.8 \%)$ was obtained using higher temperatures $\left(100^{\circ} \mathrm{C} ; 80 \mathrm{~min}\right)$. Monosaccharide composition of the pectic fractions was similar to others already described.
\end{abstract}

Keywords: Pectins, extraction, citric acid.

\section{Introduction}

Processing of waste by-products from agricultural origin generated by different kinds of industries can entail environmental problems. In the South of Brazil apple pomace (raw material for pectin production) could play an important role in pectin production, offering economic advantages and decreasing the environment impact. Pectins are derived with aggregate value and have many applications in food and pharmaceuticals products as gelling agents and stabilizers ${ }^{[1,2]}$.

The pectin composition varies with the source from which it is isolated, as well as with conditions used during isolation and purification. The industrial demand for pectins with varying ability to gel or stabilize fruit and dairy products increases the need for accessing pectins of different types or pectin derivatives with tailored properties ${ }^{[3]}$.

Pectins are complex heteropolysaccharides consisting of homogalacturonan ("smooth", $\alpha-(1 \rightarrow 4)$-linked partly methylesterified-D-GalAp-2-(1 $\rightarrow 2)$ units) and rhamnogalacturonan ("hairy", GalA $p-\alpha-(1 \rightarrow 2)-\mathrm{Rha} p-\alpha-(1 \rightarrow 4)$ GalAp$\alpha-(1 \rightarrow 2)$-Rhap) regions. In the latter, neutral sugar side chains containing mainly L-arabinose, D-galactose and $\mathrm{D}$-xylose are covalently attached to the rhamnosyl residues of the backbone $e^{[4,5]}$.

The degree of substitution of methyl esters determines the mechanism of formation of pectins gels. In high methoxyl (HM) pectins, which have a methoxyl content between $50-80 \%$, gel formation occurs by the presence of relatively high concentration of soluble solids, usually sucrose, and a low $\mathrm{pH}$. By the other hand, low methoxyl (LM) pectins, with methoxyl content of $25-50 \%$ form gels by interaction with $\mathrm{Ca}^{+2}$ by the "egg box" mechanism ${ }^{[1,2]}$. Moreover, the gelation properties of pectins are influenced by the length of their side branches, the degree of acetylation and the pattern of esterification (block-wise or random) ${ }^{[6]}$.

Pectins may be obtained on a laboratory scale by extractions of the cell-wall material using different protocols such as cold and/or hot water or buffer solutions, cold and/ or hot solutions of chelating agents, hot diluted acids, and cold diluted sodium hydroxide ${ }^{[7]}$. Pectins from citrus, apple or sugar beet pulp are mainly extracted with mineral acids.

In the present work, extractions of apple pectins were performed using $5 \%(\mathrm{w} / \mathrm{v})$ citric acid aiming to establish optimization of conditions (time and temperature) to have the highest yields.

\section{Experimental}

\section{Plant Material}

Ripe apples (variety Gala) acquired in the local market in March 2003. The fruits were cut into four pieces, milled and pressed. The pomace was dried and ground to be used as apple flour.

\section{Experimental Design}

The experimental design used was a $2^{2}$ factorial design with triplicate of central point. The concentration of extractor agent (citric acid) was $5 \%(\mathrm{w} / \mathrm{v})$ and the variables were time $(30,50$ and $80 \mathrm{~min})$ and temperature $\left(50,75\right.$ and $\left.100^{\circ} \mathrm{C}\right)$.

\section{Pectin Isolation}

Aqueous extraction: apple flour (20g) was stirred for 30 min in water at $25^{\circ} \mathrm{C}$. The residue was separated by filtration. The supernatants were concentrated under vacuum.

Acid extraction: The residue obtained in the aqueous extraction was submitted to extraction with $5 \%(\mathrm{w} / \mathrm{v})$ citric acid in different times and temperatures according to the experimental design. The sample was cooled and its residue separated by filtration. The supernatants were precipitated with ethanol ( 2 vol). After approximately 12 hours $\left(4{ }^{\circ} \mathrm{C}\right)$, the pectins were separated by filtration and dried at $35-40^{\circ} \mathrm{C}$.

Autor para correspondência: Eliana Beleski-Carneiro, Departamento de Bioquímica e Biologia Molecular, UFPR, Curitiba, PR. E-mail: ebeleski@uol.com.br 


\section{General Methods}

Flour characterization: Nitrogen was determined by the Kjeldahl method and protein content was estimated as $\mathrm{N} \mathrm{x}$ 6.25. Reduce sugar were analyzed by Somogyi-Nelson ${ }^{[8]}$. Moisture and ashes were determined by thermo gravimetric loss at 105 and $505^{\circ} \mathrm{C}^{[9]}$, respectively. Lipids were calculated as ethereal extract with hexane ${ }^{[9]}$.

Pectin characterization: Uronic acids were determined as anhydrogalacturonic acid by colorimetric determination ${ }^{[10]}$. Polysaccharides were hydrolyzed with $1 \mathrm{M}$ trifluoroacetic acid solution $\left(5 \mathrm{~h}, 100{ }^{\circ} \mathrm{C}\right)$, the hydrolyzates evaporated, the residues reduced with $\mathrm{NaBH}_{4}$, and the products acetylated with pyridine-acetic anhydride $\left(1: 1 \mathrm{v} / \mathrm{v}, 16 \mathrm{~h}\right.$, at $\left.25^{\circ} \mathrm{C}\right)$. The resulting alditol acetates were analyzed by GLC (gas-liquid chromatography) using a model 5890 S II HP Gas Chromatograph (FID and injector temperature, $250{ }^{\circ} \mathrm{C}$, and detector, $\left.300{ }^{\circ} \mathrm{C}\right)$, with a DB-210 capillary column $(0,25 \mathrm{~mm}$ i.d. $x 30 \mathrm{~m}$ ) at $220^{\circ} \mathrm{C}$ (constant), film thickness $0.25 \mu \mathrm{m}$, the carrier gas being nitrogen.

Paper chromatography (PC) was conducted by the ascending method, on Whatman $\mathrm{n}^{\mathrm{o}} 1$ paper using as solvent the system benzene-1-butanol-pyridine-water (1:5:3:3 v/v; upper phase). The sugar was detected by alkaline $\mathrm{AgNO}_{3}{ }^{[11]}$.

For each fraction protein content was determined by Hartree ${ }^{[12]}$ method, total sugar by phenol-sulphuric acid ${ }^{[13]}$ and degree of methylation by potenciometric titration.

\section{Results and Discussion}

The data from the apple flour analysis indicated: about $10 \%$ moisture, $3 \%$ protein, $30 \%$ reduced sugars, $6 \%$ starch, $2 \%$ lipids and $1.6 \%$ ashes.

Pectins fractions 1, 2, 3 and 4 were obtained from the extractions from apple pomace (after the juice extraction) using an experimental design with a $2^{2}$ factorial. A triplicate of central point resulted in pectin fraction 5, 6, 7 (Table 1).

Apple pomace has been described to contain 10-15\% of pectin on a dry matter basis ${ }^{[1]}$. In this study the yield of pectins

Table 1. Experimental design, yield, total sugar, protein and DM of apple pectins extracted with $5 \%(\mathrm{w} / \mathrm{v})$ citric acid.

\begin{tabular}{|c|c|c|c|c|c|c|}
\hline Fraction & $\begin{array}{c}\text { Temp. } \\
\left({ }^{\circ} \mathrm{C}\right)\end{array}$ & $\begin{array}{l}\text { Time } \\
\text { (min) }\end{array}$ & $\begin{array}{c}\text { Yield }^{1} \\
(\%)\end{array}$ & $\begin{array}{c}\text { Total } \\
\text { Sugar }^{2} \\
(\%)\end{array}$ & $\begin{array}{c}\text { Protein }^{3} \\
(\%)\end{array}$ & $\begin{array}{c}\mathrm{DM}^{4} \\
(\%)\end{array}$ \\
\hline 1 & 50 & 30 & 5.7 & 42.5 & 11.1 & 14.3 \\
\hline 2 & 100 & 30 & 14.0 & 48.0 & 10.8 & 29.4 \\
\hline 3 & 100 & 80 & 10.0 & 42.5 & 21.6 & 15.2 \\
\hline 4 & 100 & 80 & 16.8 & 44.3 & 11.5 & 15.4 \\
\hline $5,6,7$ & 75 & 55 & 7.2 & 45.9 & 6.0 & 17.7 \\
\hline \multicolumn{7}{|c|}{$\begin{array}{l}{ }^{1} \text { Based of dry apple flour } \\
{ }^{2} \text { Determined by Phenol Sulphuric Method } \\
3 \text { Determined by Hartree Method } \\
{ }^{4} \text { Determined by Potenciometric Titration }\end{array}$} \\
\hline
\end{tabular}

Table 2. Monosaccharide composition of apple pectins extracted with $5 \%$ (w/v) citric acid.

\begin{tabular}{ccccccccc}
\hline Fraction & $\begin{array}{c}\text { Uronic } \\
\text { acid }^{1}\end{array}$ & Rha & Fuc & Ara & Xyl & Man & Gal & Glc \\
\hline 1 & 38.6 & 5.5 & - & 28.7 & 7.4 & - & 11.0 & 8.8 \\
2 & 36.7 & 5.6 & - & 8.5 & 14.0 & - & 18.0 & 17.2 \\
3 & 33.4 & 6.0 & - & 28.0 & 11.5 & - & 11.9 & 9.2 \\
4 & 42.3 & 5.6 & - & 5.7 & 14.4 & 0.9 & 16.6 & 14.5 \\
$5,6,7$ & 42.5 & 5.4 & 1.2 & 22.5 & 7.9 & - & 10.6 & 9.8 \\
\hline
\end{tabular}

Neutral Sugar determined by g.1.c. (\%)

${ }^{1}$ Determined by Blumenkrantz and Asboe-Hansen (\%) ${ }^{[10]}$

obtained from apple pomace ranged from 5.7 to $16.8 \%$. The increase in the yield was directly correlated with the increases in time and temperature of extraction (Table1).

Total sugar content was similar for all fractions. The protein content, 6.0 to $21.6 \%$, could be overestimated by the presence of phenolic compounds. LM pectins were isolated in all approaches as could be pointed by the degree of esterification (DM), that ranged from 14.3 to $29.4 \%$. The central point showed DM $17.7 \%$.

The monosaccharide composition of pectins fractions $(1,2,3,4$ and 5,6,7) are shown in Table 2.

The qualitative profile of the pectic fractions was similar to that described by Schols et a ${ }^{[14]}$. Galacturonic acid content varied from 33.4 to $42.5 \%$ and it was not related to the extraction yields. The levels of uronic acid and the high contents of neutral sugars, mainly arabinose and galactose, suggest the presence of arabinans and galactans as side chains.

Pectins are spatially localized in cell-wall domains and its composition varies with the source and the conditions applied during isolation ${ }^{[1]}$. Different pectin subpopulations can be distinguished by their sugar composition and uronic acid amount $^{[15]}$.

The ratio Ara/Xyl and Ara/Gal decreased with the temperature increasing, independent of time, this suggest that the more effective conditions of extraction could promote hydrolysis on more labile furanosidic arabinosyl units.

As the isolation process can influence in the structure and properties of polysaccharides, the potential uses and rheological properties of these pectins need to be investigated further.

\section{Conclusion}

Relatively high yields of pectin can be reached by acid extraction at $100{ }^{\circ} \mathrm{C}$ during $80 \mathrm{~min}$. However, the data suggest that extraction conditions could have important effects on the features of extracted pectins of flour apple. Lower ratios Ara/Xyl and Ara/Gal were observed with increasing of temperature, independently of time. The quantity as well as the characteristics of the pectins varied often in a large range according to the experimental conditions of extractions. 


\section{References}

1. Rolin, C. Pectins, in: Industrial Gums: Polysaccharides and Their Derivates- 3 ed, p.257-293, Whistler, R.L.; BeMiller, J (Ed), Academic Press, San Diego (1993).

2. Ridley, B. L.; O’ Neill, A.\& Mohnen, D. Pectins: structure, biosynthesis, and oligogalacturonide-related signaling. Phytochemistry, 57, p.929 (2001).

3. Rosenbohm, C.; Lundt, I.;.Christensen, T. M..I.E. \& Young, N.W.G. Chemically methylated and reduced pectins: preparation, characterisation by ${ }^{1} \mathrm{H}$ NMR spectroscopy, enzymatic degradation and gelling properties. Carbohydr. Res., 338, p.637 (2003).

4. De Vries, J.A.; Voragen, A.G.J.; Roumbouts, F.M.; Pilnik, W. "Structural studies of apple pectins with pectolytic enzymes", in: Chemistry and Function of Pectins. p.3848. American Chemical Society, Fishman, M.L.; Jenn, J.J. (eds), Washington DC (1986).

5. Voragen, A.G.J.; Pilnik, W. \& Thibault, J.F. Pectins in: Food Polysaccharides and Their Applications, p.287-339, A.M. Stephen (ed.) Marcel Dekker, New York (1995).

6. Matthew, J.A.; Howson, S.J.; Keenan, M.H.J. \& Belton, P.S. Gelation of sugar beet and citrus pectins using enzymes extracted from orange peel. Carbohydr. Polym, 12, p.295 (1990).
7. Rombouts, F.M. \& Thibault, J. F. Feruloylated pectic substances from sugar beet pulp. Carbohydr. Res., 154, p.177 (1986).

8. Somogyi, M. Notes on sugar determination. Journal of Biological Chemistry, 195(1), p.19 (1952).

9. Instituto Adolfo Lutz. Normas Analíticas do Instituto Adolfo Lutz. $3^{a}$ ed. São Paulo: O Instituto (1985).

10. Blumenkrantz, N. \& Asboe-Hansen, G. New method for quantitative determination of uronic acids. Anal. Biochem., 54, p.484 (1973).

11. Trevelyan, W.E.; Procter, D.P. \& Harrison, J.S. Detection of sugars on paper chromatograms by use of dipping reagents. Nature, 166, p.444 (1950).

12. Hartree, E. F. Determination of protein: a modification of the Lowry method that gives a linear photometric response. Anal. Biochem., 48, p.422 (1972).

13. Dubois, M.; Gilles, K.A. \& Hamilton, J.K.; Rebers, P.A.; Smith, F. Colorimetric method for determination of sugars and related substances. Anal. Chem., 28, p.350 (1956).

14. Schols, H. A.; Vierhuis, E.; Bakx, E. J. \& Voragen, A.G.J. Different populations of pectin hairy regions occur in apple cell walls. Carbohydr. Res., 275, p.343 (1995).

15. Redgwell, R.J. \& Selvendran, R.R. Structural features of cell-wall. Polysaccharides of onion Allium cepa. Carbohydr. Res.,157, p.183 (1986). 